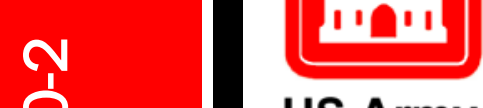

US Army Corps

of Engineers ${ }_{\circledast}$

Engineer Research and

Development Center

ERDC 6.2 Boreal Aspects of Ensured Maneuver (BAEM)

\title{
Geospatial Snow Estimation for Engineering Applications and Operations
}

E. Deeb, C. Polashenski, Z. Courville, C. Hiemstra, A. Wagner,

August 2020

J. Eylander, and R. Davis 
The U.S. Army Engineer Research and Development Center (ERDC) solves the nation's toughest engineering and environmental challenges. ERDC develops innovative solutions in civil and military engineering, geospatial sciences, water resources, and environmental sciences for the Army, the Department of Defense, civilian agencies, and our nation's public good. Find out more at www.erdc.usace.army.mil.

To search for other technical reports published by ERDC, visit the ERDC online library at http://acwc.sdp.sirsi.net/client/default. 
July 2020

\section{Geospatial Snow Estimation for Engineering Applications and Operations}

E. Deeb, C. Polashenski, Z. Courville, C. Hiemstra, A. Wagner, J. Eylander, and R. Davis U.S. Army Engineer Research and Development Center (ERDC)

Cold Regions Research and Engineering Laboratory (CRREL)

72 Lyme Road

Hanover, NH 03755-1290

Final Report

Approved for public release; distribution is unlimited.

Prepared for Assistant Secretary of the Army for Acquisition, Logistics, and Technology 103 Army Pentagon

Washington, DC 20314-1000

Under Project 465395, ERDC 6.2 “Boreal Aspects of Ensured Maneuver (BAEM)," and Project 471941, "Remote Assessment of Snow Mechanical Properties" and "Mobility in Peat and Northern Soils" 


\section{Preface}

This study was conducted for the Assistant Secretary of the Army for Acquisition, Logistics, and Technology under project number 465395, "Boreal Aspects of Ensured Maneuver (BAEM)," which is part of the U.S. Army Engineer Research and Development Center (ERDC) 6.2 Remote Assessment of Infrastructure for Ensured Maneuver (RAFTER) Program managed by Ms. Danielle Whitlow, ERDC Geotechnical and Structures Laboratory (GSL).

The work was performed by the Lidar and Wetlands Group of the Remote Sensing / Geographic Information System Center of Expertise (CEERDRS), the Terrestrial and Cryospheric Science Branch (CEERD-RRG) and the Biogeochemical Sciences Branch (CEERD-RRN) of the Research and Engineering Division (CEERD-RR), and the Office of the Technical Directors (CEERD-RZT), U.S. Army Engineer Research and Development Center, Cold Regions Research and Engineering Laboratory (ERDCCRREL). At the time of publication, Dr. Elias Deeb was lead for the Lidar and Wetlands Group; Mr. David Finnegan was Chief, CEERD-RS; Dr. John Weatherly was Chief, CEERD-RRG; Dr. Justin Berman was Chief, CEERD-RRN; and Mr. Jimmy Horne was Chief, CEERD-RR. The Deputy Director of ERDC-CRREL was Mr. David B. Ringelberg, and the Director was Dr. Joseph L. Corriveau.

This Miscellaneous Paper (MP) was published as the following:

Deeb, E., C. Polashenski, Z. Courville, C. Hiemstra, A. Wagner, J. Eylander, and R. Davis. 2019. "Geospatial Snow Estimation for Engineering Applications and Operations." In Proceedings of the 18th International Conference on Cold Regions Engineering and the Canadian Permafrost Conference, 18-22 August 2019, Quebec City, Quebec, Canada.

COL Teresa A. Schlosser was Commander of ERDC, and Dr. David W. Pittman was the Director.

DISCLAIMER: The contents of this report are not to be used for advertising, publication, or promotional purposes. Citation of trade names does not constitute an official endorsement or approval of the use of such commercial products. All product names and trademarks cited are the property of their respective owners. The findings of this report are not to be construed as an official Department of the Army position unless so designated by other authorized documents.

DESTROY THIS REPORT WHEN NO LONGER NEEDED. DO NOT RETURN IT TO THE ORIGINATOR. 


\title{
Geospatial Snow Estimation for Engineering Applications and Operations
}

\author{
E. Deeb, Ph.D. \\ Cold Regions Research and Engineering Laboratory, Hanover, New Hampshire, USA \\ C. Polashenski, Ph.D. \\ Cold Regions Research and Engineering Laboratory, Hanover, New Hampshire, USA \\ Z. Courville, Ph.D. \\ Cold Regions Research and Engineering Laboratory, Hanover, New Hampshire, USA \\ C. Hiemstra, Ph.D. \\ Cold Regions Research and Engineering Laboratory, Hanover, New Hampshire, USA
}

\author{
A. Wagner, Ph.D. \\ Cold Regions Research and Engineering Laboratory, Hanover, New Hampshire, USA \\ J. Eylander \\ Cold Regions Research and Engineering Laboratory, Hanover, New Hampshire, USA \\ R. Davis, Ph.D. \\ Cold Regions Research and Engineering Laboratory, Hanover, New Hampshire, USA
}

\begin{abstract}
The U.S. Army Corps of Engineers supports accurate terrestrial, atmospheric and environmental awareness from tactical to global scale in support of its national security, international development, and humanitarian functions. Moreover, the Cold Regions Research and Engineering Laboratory specifically estimates geospatial snow properties in support of the Corps civil works mission which include managing waterways in snow impacting watersheds, winter vehicle mobility, and other National intelligence functions. Snow is a spatially and temporally evolving medium that has a diverse set of impacts on engineering applications and operations. While some operational organizations provide general snow information with a regional to global perspective, the time and length scales do not match tactical or engineering requirements. Fine-scale spatial representation of snow requires observations or simulation of several snow characteristics including snow depth, density, albedo, stratigraphy, microstructure and temperature. The Remote Snow Assessment Team at the Cold Regions Research and Engineering Laboratory has addressed user needs through the use of a combined multisensor, modeling framework to improve global snow characterization and enable assimilation of remotely sensed observations. Case studies from both military and civil works applications are highlighted showing successful methods developed to provide high spatial/temporal resolution snow products, snow climatologies from historical analyses, and solutions to solve snow issues with respect to water resource management, flood hazard assessment, and winter mobility modeling.
\end{abstract}

KEY WORDS: Snow, remote sensing, modeling, characterization. 


\section{INTRODUCTION}

The U.S. Department of Defense (DoD) requires global terrestrial, atmospheric, and environmental awareness to support civil works and warfighting functions. Snow is a critical component of environmental awareness that can change rapidly and profoundly impact DoD operations. Domestically, the U.S. Army Corps of Engineers (USACE), under the auspices of the DoD, requires information on snow to develop accurate and timely hydrologic forecasts for water resource allocation, infrastructure design and construction, and flood forecasting. On 30 to 50\% of Earth's land area, runoff processes are dominated by snow in mountainous, temperate, boreal, and Arctic environments. Abroad, the Army requires snow information for mission planning and operations. Army warfighter functions are impacted by snow in ways ranging from hampered mobility to limited sensor performance. These impacts are highly dynamic because snow is a spatially variable and temporally evolving boundary condition. Accurate and timely snow condition information is critical to mitigating these impacts.

\section{SNOW DATA REQUIREMENTS: MILITARY AND CIVIL WORKS}

The impacts of snow on the US Army's military and civil works functions are summarized in terms of three task groupings that crosscut functional areas: sensor performance, mobility, and infrastructure. Each of these task groupings requires a specific set of snow property information to mitigate impacts on operations, which are discussed in more detail below. A command structure requires tools that integrate snow information seamlessly into the planning process to maximize success across all functions. Snow information needed for domestic civil works and stability operations is similar to that required by sustainment operations, and is therefore grouped with infrastructure. The relationship between primary mission planning variables and scientific snow metrics are listed in Figure 1. Each variable is characterized by timescale requirements (i.e. real-time, forecast, and climatology) as well as specific snow variables (i.e. flux, amount, and physical properties). Snow variables related to flux include snowfall rates; those related to amount include snow-covered area (SCA), snow depth, and snow water equivalent (SWE); and those related to the physical properties of snow include optical properties across the visible through infrared portion of the electromagnetic spectrum, snow wetness related to its dielectric properties, snow microstructure at the grain scale, and indices of snow strength. 


\begin{tabular}{|c|c|c|c|c|c|c|c|c|c|c|c|c|}
\hline \multirow[b]{3}{*}{ Task } & \multirow[b]{3}{*}{$\begin{array}{l}\text { Decision Support } \\
\text { Variable }\end{array}$} & \multirow{2}{*}{\multicolumn{3}{|c|}{ Timescale }} & \multicolumn{8}{|c|}{ Snow Variables } \\
\hline & & & & & \multirow{2}{*}{\begin{tabular}{|c|} 
Flux \\
Snowfall \\
Rates
\end{tabular}} & \multicolumn{3}{|l|}{ Amount } & \multicolumn{4}{|c|}{ Physical Properties } \\
\hline & & $\begin{array}{l}\text { Real- } \\
\text { time }\end{array}$ & Forecast & Climatology & & $\begin{array}{l}\text { Snow } \\
\text { Covered } \\
\text { Area } \\
\text { (SCA) }\end{array}$ & $\begin{array}{l}\text { Snow } \\
\text { Depth }\end{array}$ & SWE & $\begin{array}{c}\text { Optical } \\
\text { Properties }\end{array}$ & Wetness & $\begin{array}{c}\text { Micro- } \\
\text { structure }\end{array}$ & Strength \\
\hline \multicolumn{13}{|l|}{ Sensor Performance } \\
\hline Target/Adversary Detection & $\begin{array}{l}\text { Sensor efficacy, radar, electro- } \\
\text { optical signatures }\end{array}$ & $x$ & $\mathrm{x}$ & & $x$ & & $x$ & $x$ & $\mathrm{x}$ & $\mathrm{x}$ & $x$ & \\
\hline Force Concealment & $\begin{array}{l}\text { Camouflage efficacy, } \\
\text { background electromagnetic } \\
\text { signatures, acoustic } \\
\text { attenuation }\end{array}$ & $x$ & $\mathrm{x}$ & $\mathrm{x}$ & $x$ & & $\mathrm{x}$ & $\mathrm{x}$ & $x$ & $x$ & $\mathrm{x}$ & \\
\hline Terrain Analysis & $\begin{array}{l}\text { Ground state, terrain/ } \\
\text { vegetation discrimination }\end{array}$ & $x$ & $x$ & $\mathrm{x}$ & $\mathrm{x}$ & $x$ & $\mathrm{x}$ & & $\mathrm{x}$ & $x$ & $x$ & \\
\hline Buried Threat Detection & $\begin{array}{l}\text { Thermal and radar signal } \\
\text { attenuation }\end{array}$ & $\mathrm{x}$ & & & $\mathrm{x}$ & & $\mathrm{x}$ & $x$ & & $x$ & $\mathrm{x}$ & $\mathrm{x}$ \\
\hline Surveillance Sensors/Mine performance & Burial, tripwire function & $x$ & $x$ & & & & $x$ & & & & & \\
\hline Communications & Signal attenuation & $x$ & & & $x$ & & $x$ & $x$ & & $x$ & $x$ & \\
\hline \multicolumn{13}{|l|}{ Mobility } \\
\hline \multicolumn{13}{|l|}{ Austere Entry } \\
\hline Over Snow Travel & $\begin{array}{l}\text { Snow load bearing capacity, } \\
\text { traction, depth }\end{array}$ & $x$ & $\mathrm{x}$ & $\mathrm{x}$ & $x$ & $x$ & $x$ & & & $\mathrm{x}$ & $x$ & $x$ \\
\hline Avalanche Hazards & Snowpack Stability & $\mathrm{x}$ & $\mathrm{x}$ & & $\mathrm{x}$ & $\mathrm{x}$ & $\mathrm{x}$ & & & $\mathrm{x}$ & $\mathrm{x}$ & $\mathrm{x}$ \\
\hline Helicopter Landing Zones & $\begin{array}{l}\text { Rotorwash/visibility, snow } \\
\text { load bearing capacity }\end{array}$ & $x$ & $\mathrm{x}$ & & $\mathrm{x}$ & $\mathrm{x}$ & $\mathrm{x}$ & & & & $\mathrm{x}$ & $\mathrm{x}$ \\
\hline \multicolumn{13}{|l|}{ Travel on Improved Surfaces } \\
\hline Surface Movements & $\begin{array}{l}\text { Trafficability, Snow Removal } \\
\text { needs, Visibility }\end{array}$ & $x$ & $x$ & & $\mathrm{x}$ & & $x$ & & & & & $x$ \\
\hline Aircraft Landings & Visibility, Snow depth & $\mathrm{x}$ & $\mathrm{x}$ & & $\mathrm{x}$ & & $\mathrm{x}$ & & & & & $\mathrm{x}$ \\
\hline \begin{tabular}{|l} 
Vehicle Design \\
\end{tabular} & Traction, Rolling Resistance & & & $\mathrm{x}$ & & $\mathrm{x}$ & $\mathrm{x}$ & & & & $\mathrm{x}$ & $\mathrm{x}$ \\
\hline \multicolumn{13}{|c|}{ Military Infrastructure/Civil Works/Stability Operations } \\
\hline Emergency/Flooding Management & $\begin{array}{l}\text { Melt discharge/river flow } \\
\text { rates }\end{array}$ & $\mathrm{x}$ & $\mathrm{x}$ & $\mathrm{x}$ & & & & $\mathrm{x}$ & & $\mathrm{x}$ & & \\
\hline Structure Design & Snow Load, Drainage needs & $\mathrm{x}$ & $\mathrm{x}$ & $x$ & & & $\mathrm{x}$ & $\mathrm{x}$ & & & & \\
\hline Irrigation/Hydropower Management & $\begin{array}{l}\text { Melt discharge/river flow } \\
\text { rates }\end{array}$ & $\mathrm{x}$ & $\mathrm{x}$ & $\mathrm{x}$ & & & & $\mathrm{x}$ & & $\mathrm{x}$ & & \\
\hline Road Construction and Maintenance & Snow timing and depth & $\mathrm{x}$ & $x$ & $x$ & $x$ & $x$ & $x$ & & & & & \\
\hline
\end{tabular}

Figure 1 . The relationship between primary mission planning variables and scientific/engineering snow metrics.

\section{SNOW ESTIMATION APPLICATIONS}

Substantial scientific efforts have been made to understand, observe, and predict snow characteristics, including all of the identified properties required for DoD decision support. The maturity of these efforts varies widely, with some properties still requiring fundamental basic research for advancement and others ready for rapid transition into improved environmental awareness systems. The current state of scientific knowledge on snow is not fully implemented in existing models, and advances in basic understanding could push the state of knowledge further to meet the operational needs. The following are some applications of snow estimation capabilities developed through research efforts at the Cold Regions Research and Engineering Lab.

\subsection{Snow-Covered Area (SCA)}

SCA, or the spatial extent of snow cover, is one of the most commonly assessed snow variables, and has a long observational remote sensing record (Brown and Robinson, 2011; Comiso and Hall, 2014; Estilow et al., 2015). Changes in the seasonal snowpack extent can occur over a relatively short time period during snowfall and melt events, dramatically altering the operational environment. Precipitation events and melt rates can 
be highly variable at a wide range of spatial scales, making observation of the extent critical.

Time-lapse cameras can be used to monitor snow extent at a local scale, but snow covered area is most commonly observed over large areas using satellite observations, specifically electro-optical sensors operating in visible wavelengths. Snow contrasts greatly with most land cover types owing to its high albedo, therefore it can be easily detected at high-resolution using optical sensors. Multispectral sensors (e.g. AVHRR, MODIS, and Landsat) are frequently used to calculate snow cover or snow-covered fraction (SCF). Snow presence or absence is relatively easy to determine. However, accuracy can be greatly impacted by the presence of clouds, density of overlying forest canopy, and existing substrates of similar color (e.g. sea ice, glacial ice); in addition, imagery cannot be collected at night. Nevertheless, optical satellite estimates of SCA on land have been found to be highly accurate over large spatial extents (Gafurov and Bárdossy, 2009). Figure 2 depicts SCA across the snow-impacted watersheds of Afghanistan taken from the bi-weekly CRREL and Air Force Weather snow assessment report and is based on a time-filtered daily reflectance product from the VIIRS instrument aboard the NASA/NOAA Suomi-NPP satellite (Daly et al., 2012; Morriss et al., 2016).

\section{Afghanistan Snow Covered Area}

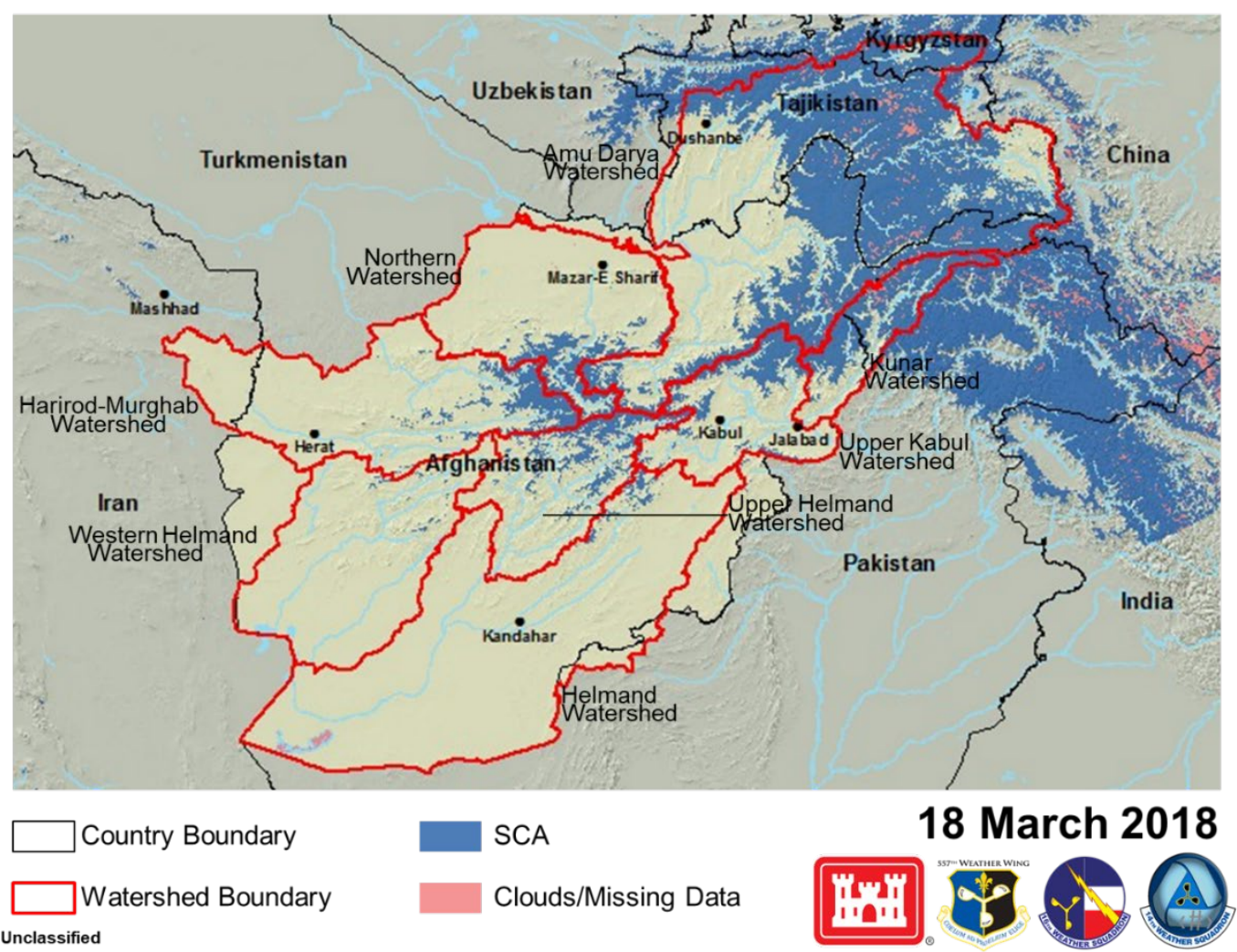

Figure 2. Temporal filtered snow-covered area for the snow-impacted watersheds of Afghanistan estimated from the VIIRS instrument aboard the Suomi-NPP satellite. 


\subsection{Snow Water Equivalent (SWE)}

Snow water equivalent (SWE), the volume of water contained in the snowpack, is a critical parameter for hydrologic applications. In many regions, peak annual SWE is highly correlated to the total volumetric spring runoff, and can be used for forecasting purposes. SWE directly influences flood or drought potential, water resource availability and groundwater recharge. SWE is often estimated as the product of snow depth observations and measurements or models of snow density (Sturm et al., 2010; McCreight and Small, 2014).

SWE can also be estimated remotely by measuring the passive micro-wave signal naturally emitted from the Earth (Tedesco et al., 2006; Derksen, 2008; Kelly, 2009; Frei et al., 2012; Vander Jagt et al., 2013). A passive microwave signal at frequencies greater than $\sim 25 \mathrm{GHz}$ is scattered as it passes through the snowpack. Estimation of SWE can be made from this signal attenuation using empirical relationships or microwave emission models. Space-based observations of microwave emission have been available for more than three decades, providing a long historical record. However SWE data produced from the microwave signal are fairly coarse $(25 \mathrm{~km})$ and affected by multiple other factors including deep snow, snow metamorphism, snow wetting and vegetation which impact the accuracy of the snow estimation. Figure 3 shows an example of the historical passive microwave SWE record statistics showing the seasonal accumulation and ablation phase of the snowpack as reported in the CRREL and Air Force Weather bi-weekly snow assessment products. The current year trend indicates historically low (based on the period of record) snow volume through 18 March 2018 with likely drought conditions heading into spring.

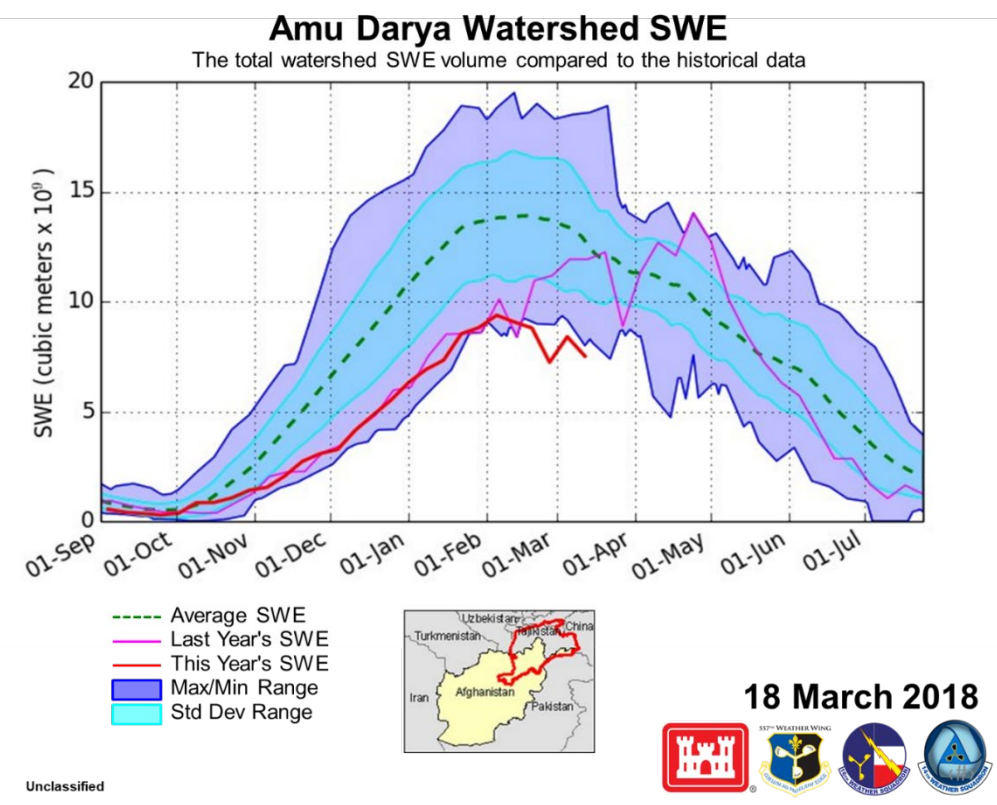

Figure 3. Historical (1987 to present) passive microwave satellite assessment of snow water equivalent for the largest snow-impacted watershed in Afghanistan (Amu Darya). Chart shows the historical max/min, average, and standard deviation across the winter 
accumulation and spring ablation season. For perspective, the annual SWE trend for last season (2016-2017) is shown alongside the current year (2017-2018) as of 18 March 2018.

\subsection{Global Snow Estimation and Snow Climatologies}

From a DoD planning and operations perspective, climatological data and long-term predictions are needed for infrastructure design and equipment investment decisions, as well as to provide historical context. Numerous field studies on spatial variability across multiple scales have found that the dominant control on variability of snow accumulation and melt at the watershed scale $(>100 \mathrm{~m})$ is topography, specifically elevation and aspect (Clark et al., 2011). Snowmelt processes and local scale runoff express significant variability at hill slope scales below $1 \mathrm{~km}$, where vegetation and snow redistribution have a significant and complex influence on the energy balance. For regions greater than 1 ha, explicit representation of sub-grid variability has been found to greatly improve spatially distributed snowpack modeling due to the nonlinearity of snow processes (Luce et al., 1999).

However, relatively few observational datasets exist that can provide such distributions and capture their evolution over time, and fewer still are incorporated into modeling tools to improve output. Historical snow pattern data and snow climatology information can be used to spatially infill sparse observations and downscale coarse resolution data. Development of an updated snow climatology spanning relevant length scales (Marshall et al. 2006) and incorporating snow pattern information is a key step to improving global snow estimation and informing operational mobility models.

From a northern hemisphere perspective, Figure 4 provides an example of snow cover likelihood using a statistical approach applied to the Finnish Meteorological Institute's historical GlobSnow snow extent product.

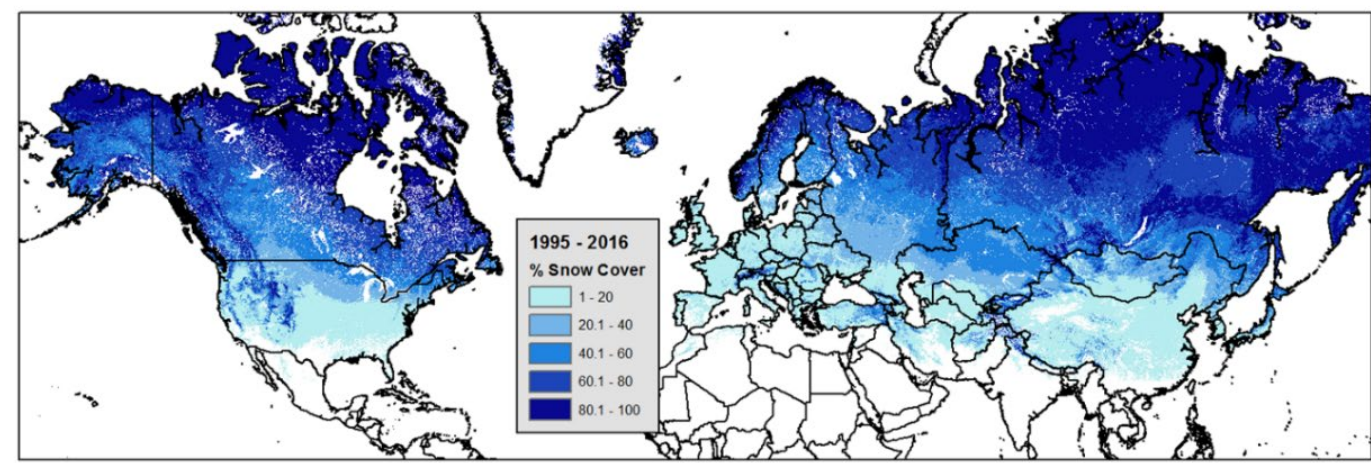

Figure 3. Northern hemisphere snow cover likelihood (October through May, 19952016) based on snow extents products from optical satellite remote sensing products. 


\section{CONCLUSIONS}

Snow operational support can be grouped into four broad categories: (1) the need for improved remote data collection, enabled by enhanced remote sensing signal processing and algorithm development; (2) the need for improved ground-based data collection, sharing, and archiving; (3) the need to confront data synthesis and scaling issues, and (4) our limited understanding of key processes needed for model development. Often these gaps overlap or require work on multiple fronts in order to fully address. This work identifies key requirements for snow estimation and some examples of efforts being pursued to address gaps in technology, methods, and models. Continued advancements in snow science and research activities span the snow research community from snow process understanding, to sensor and algorithm development, to advanced computational processing and assimilation techniques.

\section{ACKNOWLEDGMENTS}

Funding for this project begun under two work units under the Assistant Secretary of the Army for Acquisition, Logistics, and Technology: Army Terrestrial Environmental Modeling and Intelligence System (ARTEMIS) under the Army 6.2 Applied Sciences Research Program, and Snow Research to Support Mission Planning and Operations under U.S. Army Program Element 0603734A, Military Engineering Advanced Technology.

Elements of the project continues under project number 465395, "Boreal Aspects of Ensured Maneuver (BAEM)," which is part of the U.S. Army Engineer Research and Development Center (ERDC) 6.2 Remote Assessment of Infrastructure for Ensured Maneuver (RAFTER) Program managed by Ms. Danielle Whitlow. This work is continuing under project number 471941 "Remote Assessment of Snow Mechanical Properties" under the Entry and Sustainment in Complex Contested Environments Program managed by Dr. John Rushing. 


\section{REFERENCES}

Brown, R. D., and Robinson, D. A. (2011). Northern Hemisphere spring snow cover variability and change over 1922-2010 including an assessment of uncertainty. The Cryosphere 5, no. 1: 219-229.

Clark, M. P., J. Hendrikx, A. G. Slater, D. Kavetski, B. Anderson, N. J. Cullen, T. Kerr, E. Örn Hreinsson, and R. A. Woods (2011). Representing spatial variability of snow water equivalent in hydrologic and land-surface models: A review. Water Resources Research 47, no. 7.

Comiso, J. C., and Hall, D. K. (2014). Climate trends in the Arctic as observed from space. Wiley Interdisciplinary Reviews: Climate Change 5, no. 3: 389-409.

Daly, S., Vuyovich, C., Deeb, E., Newman, S., Baldwin, T., and Gagnon, J. (2012). Assessment of the snow conditions in the major watersheds of Afghanistan using multispectral and passive microwave remote sensing. Hydrological Processes, 26, 2631-2642.

Derksen, C. "The contribution of AMSR-E 18.7 and $10.7 \mathrm{GHz}$ measurements to improved boreal forest snow water equivalent retrievals." Remote Sensing of Environment 112, no. 5 (2008): 2701-2710.

Estilow, T. W., Young, A. H., and Robinson, D. A. (@015). A long-term Northern Hemisphere snow cover extent data record for climate studies and monitoring. Earth System Science Data 7, no. 1: 137.

Frei, A., M. Tedesco, S. Lee, J. Foster, D. K. Hall, R. Kelly, and D. A. Robinson (2012). A review of global satellite-derived snow products. Advances in Space Research 50, no. 8: 1007-1029.

Gafurov, A., and Bárdossy, A. (2009). Snow cover data derived from MODIS for water balance applications. Hydrology \& Earth System Sciences Discussions 6, no. 1.

Kelly, R. (2009). The AMSR-E snow depth algorithm: Description and initial results. Journal of the Remote Sensing Society of Japan 29, no. 1: 307-317.

Luce, C. H., D. G. Tarboton, and K. R. Cooley (1999). Sub-grid parameterization of snow distribution for an energy and mass balance snow cover model. Hydrological Processes 13, no. 12: 1921-1933.

Marshall, H., G. Koh, M. Sturm, J. Johnson, M. Demuth, C. Landry, J. Deems, and A. Gleason (2006). Spatial variability of the snowpack: Experiences with measurements at a wide range of length scales with several different high precision instruments. International Snow Science Workshop Proceedings, Telluride, CO, October 2006.

McCreight, J. L., E. E. Small, and K. M. Larson. "Snow depth, density, and SWE estimates derived from GPS reflection data: Validation in the west-ern US." Water Resources Research 50, no. 8 (2014): 6892-6909.

Morriss, B.F., Ochs, E., Deeb, E. J., Newman, S. D., and Daly, S. F., and Gagnon, J. J. (2016). Persistence-based temporal filtering for MODIS snow products. Remote Sensing of Environment, 175:130-137.

Sturm, M., B. Taras, G.E. Liston, C. Derksen, T. Jonas, and J. Lea. "Estimating snow water equivalent using snow depth data and climate classes." Journal of Hydrometeorology 11, no. 6 (2010): 1380-1394. 
Tedesco, M., E. J. Kim, D. Cline, T. Graf, T. Koike, R. Armstrong, M.J. Brodzik, and J. Hardy. (2006). Comparison of local scale measured and modelled brightness temperatures and snow parameters from the CLPX 2003 by means of a dense medium radiative transfer theory mod-el. Hydrological Processes 20, no. 4: 657-672.

Vander Jagt, B. J., M. T. Durand, S. A. Margulis, E. J. Kim, and N. P. Molotch (2013). The effect of spatial variability on the sensitivity of passive microwave measurements to snow water equivalent." Remote sensing of environment 136: 163-179. 


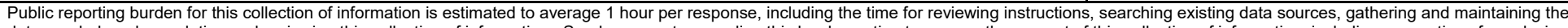

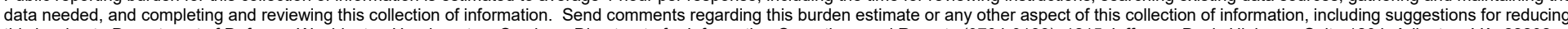

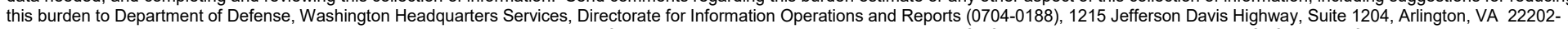

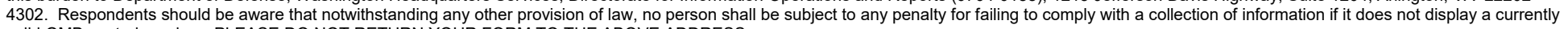
valid OMB control number. PLEASE DO NOT RETURN YOUR FORM TO THE ABOVE ADDRESS.
1. REPORT DATE (DD-MM-YYYY)
2. REPORT TYPE
3. DATES COVERED (From - To)

July 2020

\section{TITLE AND SUBTITLE}

Final

5a. CONTRACT NUMBER

Geospatial Snow Estimation for Engineering Applications and Operations

5b. GRANT NUMBER

5c. PROGRAM ELEMENT NUMBER

6. AUTHOR(S)

E. Deeb, C. Polashenski, Z. Courville, C. Hiemstra, A. Wagner, J. Eylander, and R. Davis

5d. PROJECT NUMBER

465395

5e. TASK NUMBER

\section{5f. WORK UNIT NUMBER}

\section{PERFORMING ORGANIZATION NAME(S) AND ADDRESS(ES)}

Cold Regions Research Laboratory

U.S. Army Engineer Research and Development Center

72 Lyme Road

Hanover, NH 03755

\section{SPONSORING / MONITORING AGENCY NAME(S) AND ADDRESS(ES)}

Assistant Secretary of the Army (AL\&T)

103 Pentagon

Washington, DC 20314

\section{DISTRIBUTION / AVAILABILITY STATEMENT}

Approved for public release; distribution is unlimited.

\section{SUPPLEMENTARY NOTES}

Originally published in Proceedings of the 18th International Conference on Cold Regions Engineering and $8^{\text {th }}$ Canadian Permafrost Conference, 18-22 August 2019, Quebec City, Quebec, Canada.

\section{ABSTRACT}

The U.S. Army Corps of Engineers supports accurate terrestrial, atmospheric and environmental awareness from tactical to global scale in support of its national security, international development, and humanitarian functions. Moreover, the Cold Regions Research and Engineering Laboratory specifically estimates geospatial snow properties in support of the Corps civil works mission which include managing waterways in snow impacting watersheds, winter vehicle mobility, and other National intelligence functions. Snow is a spatially and temporally evolving medium that has a diverse set of impacts on engineering applications and operations. While some operational organizations provide general snow information with a regional to global perspective, the time and length scales do not match tactical or engineering requirements. Fine-scale spatial representation of snow requires observations or simulation of several snow characteristics including snow depth, density, albedo, stratigraphy, microstructure and temperature. The Remote Snow Assessment Team at the Cold Regions Research and Engineering Laboratory has addressed user needs through the use of a combined multi-sensor, modeling framework to improve global snow characterization and enable assimilation of remotely sensed observations. Case studies from both military and civil works applications are highlighted showing successful methods developed to provide high spatial/temporal resolution snow products, snow climatologies from historical analyses, and solutions to solve snow issues with respect to water resource management, flood hazard assessment, and winter mobility modeling.

\section{SUBJECT TERMS}

Snow, remote sensing, modeling, characterization

\begin{tabular}{|c|c|c|c|c|c|}
\hline 16. SECURITY CL & IFICATION OF: & & 17. LIMITATION & 18. NUMBER & 19a. NAME OF RESPONSIBLE PERSON \\
\hline $\begin{array}{l}\text { a. REPORT } \\
\text { Unclassified }\end{array}$ & $\begin{array}{l}\text { b. ABSTRACT } \\
\text { Unclassified }\end{array}$ & $\begin{array}{l}\text { c. THIS PAGE } \\
\text { Unclassified }\end{array}$ & SAR & 12 & $\begin{array}{l}\text { 19b. TELEPHONE NUMBER } \\
\text { (include area code) }\end{array}$ \\
\hline
\end{tabular}

